\title{
Accurate Determination of Trace Cadmium in Geological Reference Materials by Closed Vessel Acid Digestion ETAAS
}

\author{
Chen $\mathrm{Du}^{\mathrm{a}}$, Lu Luo ${ }^{\mathrm{a}}$, Wei Guo*, Lanlan Jin ${ }^{\mathrm{a}}$, Bin Chen ${ }^{\mathrm{b}}$, Shenghong $\mathrm{Hu}^{\mathrm{a} *}$ \\ ${ }^{a}$ State Key Laboratory of Biogeology and Environmental Geology, \\ China University of Geosciences, 430074, Wuhan, China \\ ${ }^{b}$ China National Environmental Monitoring Centre, Beijing, 100012, P. R. China
}

\section{INTRODUCTION}

In solid earth geochemistry, Cd is generally classified as a trace element that has both lithophile and chalcophile characteristics. The $\mathrm{Cd}$ content of geological samples is usually low (typical quantities are $\left.0.01-0.5 \mu \mathrm{g} \mathrm{g}^{-1}\right)(1,2)$. The geochemistry of Cd in the ocean and marine sediments has attracted significant scientific interest for more than 30 years. This interest is primarily based on the observation that dissolved Cd concentrations in seawater show a correlation with the distribution of the marine macronutrient phosphate (3). In addition, accurate determination of Cd is imperative for Cd isotopic analysis, which in turn is important for the study of cosmology, tracing anthropogenic sources, micronutrient cycling, and ocean productivity.

In routine geological analysis, inductively coupled plasma mass spectrometry (ICP-MS) is the most commonly used method to determine $\mathrm{Cd}$ in various samples (4-8). However, the significant limitations of this technology are isobaric and/or polyatomic interferences, which derive from the presence of high concentrations of matrix elements (9). All isotopes of Cd can have interferences from various isobaric ions and/or oxide or hydroxide ions of Pd, Sn, In, Zr, Mo, Ru, $\mathrm{Nb}$, and $\mathrm{Y}$. Therefore, complicated separation procedures (chromatography, precipitation, extraction, and volatile species generation, etc.) are usually required to elimi-

\footnotetext{
*Corresponding autbors.

E-mail:Wei.Guo@cug.edu.cn (Wei Guo)

E-mail: sbbu@cug.edu.cn (Shengbong Hu)
}

\section{ABSTRACT}

Accurate determination of trace cadmium $(<0.2 \mu \mathrm{g} / \mathrm{g})$ in geological samples is of importance in geochemistry and ocean chemistry. In this paper, we describe an optimized closed vessel acid digestion-electrothermal atomic absorption spectrometry (ETAAS) method for Cd determination in various geological standard reference materials (SRMs). After decomposition of the solid samples with a mixed solution of nitric acid and hydrofluoric acid, the digest solution was introduced into a graphite atomizer and quantified by ETAAS. The pyrolysis temperature, atomization temperature, and the matrix modifier concentration parameters used for analysis were optimized for maximum sensitivity and the lowest background. The limit of quantitation and characteristic mass were $0.75 \mathrm{ng} \mathrm{g}^{-1}$ and $0.8 \pm 0.1 \mathrm{pg}$, respectively. The proposed method was applied to the determination of $\mathrm{Cd}$ in 51 geological SRMs (soil, sediment, and rock). Most of the results $(\mathrm{N}=47)$ were found to be in good agreement with the certified values or published literature values determined by isotope dilution mass spectrometry (ID-ICP-MS or IDTIMS). Additionally, we determined the Cd levels in four other reference materials by this method and reported them here for the first time. For these SRMs, 10 separate aliquots of the sample were digested and analyzed over a three-month period; the consistent results indicated that the determined values are reasonable. The proposed method thus shows great potential for the accurate determination of trace $\mathrm{Cd}$ in various geological samples. nate these interferences (10-13). Recently, isotope dilution ICP-MS (ID-ICP-MS) (14) and dynamic reaction cell ${ }^{\mathrm{TM}}$ ICP-MS (DRC ${ }^{\mathrm{TM}}$ ICP-MS) (15) have been demonstrated as valid methods to accurately detect trace Cd in geological samples. However, high cost and complex operating procedures obviate the routine use of these methods in a high-throughput geological laboratory. Compared to ICP-MS, electrothermal atomic absorption spectrometry (ETAAS) has emerged as a better technique for trace $\mathrm{Cd}$ $\left(<0.2 \mu \mathrm{g} \mathrm{g}^{-1}\right)$ analysis in a variety of samples owing to its advantages such as relatively fewer spectral interferences, high selectivity and sensitivity, good detection limits, and low cost (16-20). Therefore, ETAAS is an appropriate technique to be considered for the determination of trace levels of Cd in geological samples.

The main purpose of this work was the development of a validated method for the efficient determination of trace $\mathrm{Cd}$ in geological samples using closed vessel acid digestion ETAAS. A selection of 51 geological standard reference materials (SRMs) of different types was evaluated by the method under study. We found that this technique works well for trace Cd determination in various geological samples.

\section{EXPERIMENTAL}

\section{Instrumentation}

A PinAAcle ${ }^{\mathrm{TM}}$ 900T atomic absorption spectrometer (PerkinElmer Inc., Shelton, CT, USA) described in detail elsewhere (15) was used. The instrument was equipped with a transversely 
heated graphite atomizer $\left(\mathrm{THGA}^{\mathrm{TM}}\right)$, a longitudinal AC Zeeman background correction system, a Cd hollow cathode lamp (HCL), a TubeView $^{\mathrm{TM}}$ color furnace camera, and an AS-900 autosampler. For comparison, values measured by ICP-QMS using an ELAN ${ }^{\circledR} 9000$ quadrupole ICP mass spectrometer (PerkinElmer Inc., USA) was used.

Reagents, Standards and Geological Reference Materials

Deionized water $\left(18.2 \mathrm{M} \Omega \mathrm{cm}^{-1}\right)$ used for the preparation of all blanks, sample solutions, and standards was obtained from a Milli-Q ${ }^{\circledR}$ water purification system (Millipore Corporation, France). A single-element Cd standard (PerkinElmer No. N9300176) and matrix modifier (PerkinElmer No. B0190635, 10\% Pd as nitrate) were used. Calibration curves were constructed by online auto-dilution of a $1.0 \mu \mathrm{g} \mathrm{L}{ }^{-1}$ working stock Cd standard solution using the AS-900 autosampler. Nitric acid $\left(\mathrm{HNO}_{3}\right.$, 99.999\%), hydrogen peroxide $\left(\mathrm{H}_{2} \mathrm{O}_{2}, 99.999 \%\right)$, and hydrofluoric acid (HF, 99.999\%) were purchased from Alfa Aesar Ltd. (Tianjin, P.R. China). The accuracy of the method was assessed by using 11 international geological SRMs from USGS (United States Geological Survey, USA) and 40 Chinese SRMs from IGGE (Institute of Geophysical and Geochemical Prospecting, P.R. China).

\section{Closed Vessel Acid Decomposi- tion Procedure}

Fifty milligrams of powdered sample $(<200$ mesh) was placed in a homemade PTFE-lined stainless steel bomb, to which were added $4.0 \mathrm{~mL}$ of $\mathrm{HNO}_{3}$ and $0.4 \mathrm{~mL}$ of $\mathrm{H}_{2} \mathrm{O}_{2}$. The sealed bomb was kept at room temperature for eight hours to remove the organic material present in some of the samples; then evaporated to dryness on a heating block $\left(120^{\circ} \mathrm{C}\right)$. The bomb was sealed after the addition of $1.0 \mathrm{~mL}$ of $\mathrm{HNO}_{3}$ and $1.0 \mathrm{~mL}$ of $\mathrm{HF}$, and then placed in an electric oven and heated to $190{ }^{\circ} \mathrm{C}$ for 48 hours. After cooling, the bomb was opened and placed on a heating block $\left(120^{\circ} \mathrm{C}\right)$ and evaporated to incipient dryness (but not baked). In order to remove $\mathrm{HF}, 1.0 \mathrm{~mL}$ of $\mathrm{HNO}_{3}$ was added and evaporated to dryness, and the procedure was repeated. The residue was dissolved by adding $0.5 \mathrm{~mL}$ of $\mathrm{HNO}_{3}$ and $1.0 \mathrm{~mL}$ of deionized water. The capped bomb was placed in an electric oven and heated to $190{ }^{\circ} \mathrm{C}$ for 12 hours. The final solution was made up to $12.5 \mathrm{~mL}$ by the addition of deionized water. A reagent blank solution was prepared using the same method. As a routine decomposition method in our laboratory, the procedure is generally much more efficient than conventional wet digestions in open vessels: the loss of volatile elements is prevented, the quantity of reagent is reduced, and the decomposition of insoluble minerals is more complete.

\section{RESULTS AND DISCUSSION}

\section{Accuracy of Conventional ICP-QMS for Trace Cd Analysis}

ICP-QMS has been commonly used for trace element analysis in a variety of samples. To determine the Cd accuracy of the ICP-MS method, we employed it for the analysis of a series of international geological SRMs (with levels of Cd $<1 \mu \mathrm{g} \mathrm{g}^{-1}$ ). Of the 51 SRMs analyzed, 27 showed results outside of the certified range, as shown in Figure 1. Compared to the certified values, the relative errors (ER) of Cd determined ranged from $+17 \%$ to $+548 \%$. The wide error range was most likely due to the interferences of the polyatomic ions ${ }^{94} \mathrm{Zr}^{16} \mathrm{OH},{ }^{92} \mathrm{Zr}^{18} \mathrm{OH},{ }^{94} \mathrm{Mo}^{16} \mathrm{OH}$, and ${ }^{95} \mathrm{Mo}^{16} \mathrm{O}$. The interference from $\mathrm{ZrOH}^{+}$on ${ }^{111} \mathrm{Cd}$ was not negligible due to the high $\mathrm{Zr}$ content relative to $\mathrm{Cd}(\mathrm{Zr} / \mathrm{Cd}$ values ranging from 222 to 6049). The absolute error $\left(\mathrm{Cd}_{\text {test }}-\mathrm{Cd}_{\mathrm{ref}}\right)$ correlated well with an increase in the $\mathrm{Zr}$ content $\left(\mathrm{R}^{2}=0.76\right.$, Figure 2$)$. For most of the geological samples, especially rock samples, ICP-MS with mathematical correction was not

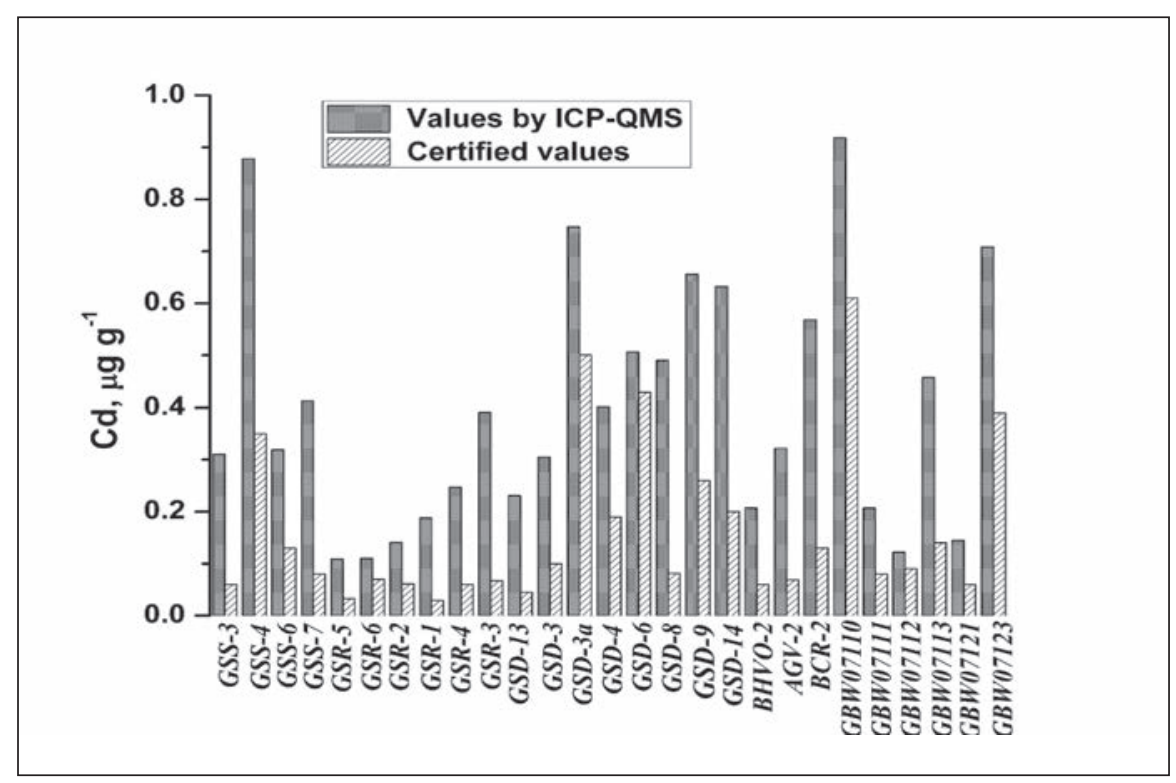

Fig. 1. Cd values in 27 geological SRMs determined by ICP-QMS and the certified values. 
sufficiently accurate when low Cd concentrations $\left(\sim 0.2 \mu \mathrm{g} \mathrm{g}^{-1}\right)$ were accompanied by high matrix levels of $\mathrm{Zr}$ and/or Mo.

\section{Optimization of the Closed Vessel Acid Digestion ETAAS Method}

Volatile elements such as Cd can be easily lost from the graphite platform at temperatures higher than $300{ }^{\circ} \mathrm{C}$ in the absence of a modifier (21). To increase the thermal stability of Cd and allow higher pryolysis temperatures for the removal of high levels of concomitants, $\mathrm{Pd}\left(\mathrm{NO}_{3}\right)_{2}$ solutions were assayed as a matrix modifier. Amounts of matrix modifier between $0.01 \%$ and $0.20 \%$ were studied; the best signalto-background ratios were obtained when $0.05 \% \mathrm{Pd}\left(\mathrm{NO}_{3}\right)_{2}$ was added. The temperature program of the graphite furnace, when properly optimized, minimizes interferences in the analysis and allows calibration with aqueous standard solutions. The optimal pyrolysis and atomization temperatures that gave the best sensitivity and lowest background signal for the geological sample (SRM AGV-2) were $600{ }^{\circ} \mathrm{C}$ and $1500{ }^{\circ} \mathrm{C}$, respectively. Under the optimized graphite furnace and spectrometer operating conditions used for a single run (Table I), the limit of quantitation (LOQ, ten times the standard deviation produced by the blank) was $0.75 \mathrm{ng} \mathrm{g}^{-1}$ for $\mathrm{Cd}$, when taking into account the dilution factor (250-fold). Since the characteristic mass is $0.8 \pm 0.1 \mathrm{pg} \mathrm{Cd}$, this sensitivity is sufficient for trace Cd analysis in soil, sediment, and rock samples where the Cd level is generally $0.02-0.5 \mu \mathrm{g} \mathrm{g}^{-1}$.

\section{Analytical Results of Cd in Geological SRMs}

The accuracy of our method was assessed using 11 USGS geological related SRMs (Table II). For comparison, the Cd certified or reference values of USGS and literaturereported values are also listed in Table II. Cd values determined for the SRMs AGV-2, BCR-2, SBC-1, SGR-1b, and BIR-1a are in agreement with the USGS reference values, except for basalt BHVO-2. The USGS reference value of $\mathrm{BHVO}-2$ is $0.06 \mu \mathrm{g} \mathrm{g}^{-1}$, which is lower than our reported value $0.107 \pm 0.008 \mu \mathrm{g} \mathrm{g}^{-1}$. However, our result is similar to the values obtained using isotope dilution ICP-MS [0.112 $\mu \mathrm{g} \mathrm{g}^{-1}$ by Makishim et al. (22)] or TIMS

\section{Atomic Apectroscopy \\ 1 Vol. 36(3), May/June 2015}

[0.094 $\mu \mathrm{g} \mathrm{g}^{-1}$ by Bouman et al. (23)]. For BCR-2, the Cd levels obtained by ICP-QMS [0.227 $\mu \mathrm{g} \mathrm{g}^{-1}$ (24), and $0.75 \mu \mathrm{g} \mathrm{g}^{-1}$ (25), etc.] are significantly higher than the USGS reference values $\left(0.14 \mu \mathrm{g} \mathrm{g}^{-1}\right)$ and the values obtained by ID-ICP-MS [0.136 $\mu \mathrm{g} \mathrm{g}^{-1}$ (26)], ID-TIMS [(0.134 $\mu \mathrm{g} \mathrm{g}^{-1}$ (23)], or our ETAAS method $\left(0.155 \pm 0.013 \mu \mathrm{g} \mathrm{g}^{-1}\right)$. The large ERs obtained using the ICP-QMS method could be attributed to the presence of large amounts of $\mathrm{Zr}$ $(\mathrm{Zr} / \mathrm{Cd}>1880)$ and Mo (Mo/Cd $>2510$ ) in BCR-2, which further confirms that our ETAAS method is more reliable than ICP-QMS. Our Cd results for dolerite DNC-1 and rhyolite RGM-2 (with low contents of $\mathrm{Zr}$ and Mo) are $0.071 \pm 0.006 \mu \mathrm{g}$ $\mathrm{g}^{-1}$ and $0.081 \pm 0.006 \mu \mathrm{g} \mathrm{g}^{-1}$, respectively, which are consistent with the values reported by $\mathrm{Hu}$ et al. (25). Cd concentrations in dolerite DNC-1a, granodiorite GSP-2, and carbonates COQ-1 SRMs are determined to be $0.079 \pm 0.007 \mu \mathrm{g} \mathrm{g}^{-1}$, $0.106 \pm 0.008 \mu \mathrm{g} \mathrm{g}^{-1}$, and $0.556 \pm$ $0.042 \mu \mathrm{g} \mathrm{g}^{-1}$, respectively. There are no previously reported Cd levels for these samples available. Ten separate aliquots of these SRMs were digested and analyzed over a period of three months and consis-

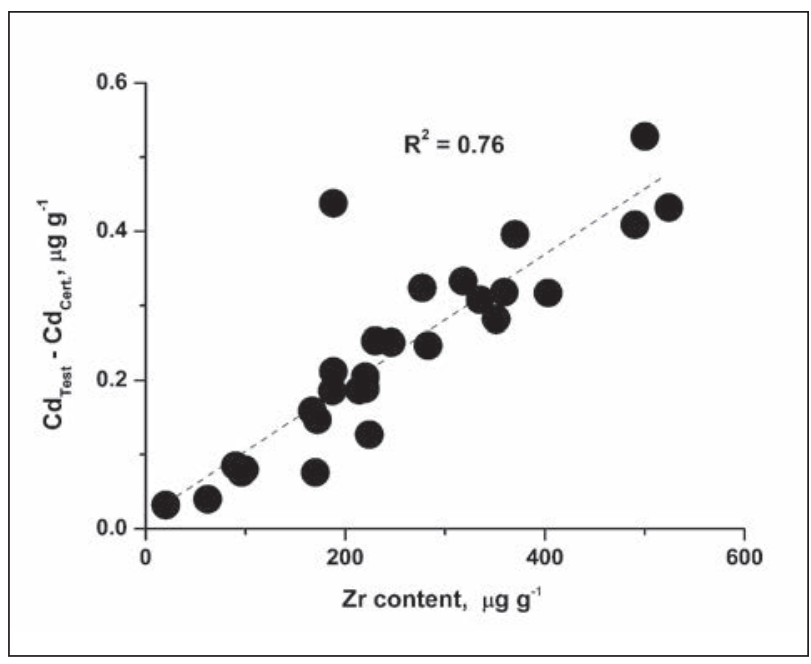

Fig. 2. Differences between Cd values determined by ICP-QMS in 27 geological SRMs and the certified values as a function of $\mathrm{Zr}$ content.
TABLE I

Graphite Furnace Temperature Programs and GF Spectrometer Operating Conditions

\begin{tabular}{|c|c|c|c|c|}
\hline Step & $\begin{array}{c}\text { Temperature } \\
\left({ }^{\circ} \mathrm{C}\right)\end{array}$ & $\underset{(s)}{\operatorname{Ramp}}$ & $\begin{array}{l}\text { Hold } \\
\text { (s) }\end{array}$ & $\begin{array}{l}\text { Argon Flow } \\
\left(\mathrm{mL} \mathrm{min}^{-1}\right)\end{array}$ \\
\hline Drying 1 & 110 & 1 & 30 & 250 \\
\hline Drying 2 & 130 & 15 & 30 & 250 \\
\hline Pyrolysis & 500 & 10 & 20 & 250 \\
\hline Atomization & 1600 & 0 & 5 & 0 \\
\hline Cleaning & 2450 & 1 & 3 & 250 \\
\hline \multicolumn{3}{|c|}{ Wavelength } & \multicolumn{2}{|c|}{$228.8 \mathrm{~nm}$} \\
\hline \multicolumn{3}{|c|}{ Spectral bandwidth } & \multicolumn{2}{|c|}{$0.7 \mathrm{~nm}$} \\
\hline \multicolumn{3}{|c|}{ Cathode lamp intensity } & \multicolumn{2}{|c|}{$8 \mathrm{~mA}$} \\
\hline \multicolumn{3}{|c|}{ Integration time } & \multicolumn{2}{|c|}{$5 \mathrm{~s}$} \\
\hline \multicolumn{3}{|c|}{ Measurement mode } & \multicolumn{2}{|c|}{ Peak area } \\
\hline \multicolumn{3}{|c|}{ Injection volume } & \multicolumn{2}{|c|}{$20 \mu \mathrm{L}$} \\
\hline \multicolumn{5}{|c|}{ Zeeman-effect background correction system } \\
\hline \multicolumn{5}{|c|}{ Pyrolytic graphite tubes with platform } \\
\hline
\end{tabular}


TABLE II

Analytical Results for Cd Obtained in this Study and in Previous Studies in USGS Geological SRMs ( $\mu \mathrm{g} \mathrm{g}^{-1}$

\begin{tabular}{lcll}
\hline $\begin{array}{l}\text { USGS Geological } \\
\text { SRMs }\end{array}$ & $\begin{array}{c}\text { This Study } \\
(\mathrm{N}=10)\end{array}$ & $\begin{array}{l}\text { USGS Ref. } \\
\text { Value }\end{array}$ & \multicolumn{1}{c}{ Literature Values } \\
\hline AGV-2 Andesite & $0.066 \pm 0.004$ & $(0.061)^{*}$ & $0.090^{\mathrm{a}}, 0.121^{\mathrm{b}}, 0.082^{\mathrm{c}}$ \\
BCR-2 Basalt & $0.155 \pm 0.013$ & $(0.14)$ & $\begin{array}{l}0.227^{\mathrm{b}}, 0.75^{\mathrm{c}}, 0.134^{\mathrm{d}} \\
0.136^{\mathrm{e}}\end{array}$ \\
& & & $0.112^{\mathrm{a}}, 0.094^{\mathrm{d}}$ \\
BHVO-2 Basalt & $0.107 \pm 0.008$ & $(0.06)$ & - \\
SBC-1 Shale & $0.410 \pm 0.012$ & $(0.4)$ & - \\
SGR-1b Oil Shale & $0.925 \pm 0.076$ & $(0.9)$ & $1.14^{\mathrm{c}}$ \\
DNC-1 Dolerite & $0.071 \pm 0.006$ & - & $0.085^{\mathrm{c}}$ \\
DNC-1a Dolerite & $0.079 \pm 0.007$ & - & - \\
COQ-1 Carbonate & $0.556 \pm 0.042$ & - & - \\
BIR-1a Basalt & $0.093 \pm 0.008$ & $(0.097)$ & $0.095^{\mathrm{c}}, 0.097^{\mathrm{d}}$ \\
GSP-2 Granodiorite & $0.106 \pm 0.008$ & - & - \\
RGM-2 Rhyolite & $0.081 \pm 0.006$ & - & $0.066^{\mathrm{c}}$ \\
\hline
\end{tabular}

* Reference value by USGS.

a ID-ICP-MS value by Makishim et al. (22)

${ }^{b}$ ICP-QMS value by Marx and Kamber. (24)

${ }^{c}$ ICP-QMS value by $\mathrm{Hu}$ and Gao. (25)

${ }^{\mathrm{d}}$ ID-TI-MS value by Bouman et al. (23)

e ID-ICP-MS value by Loss et al. (26)

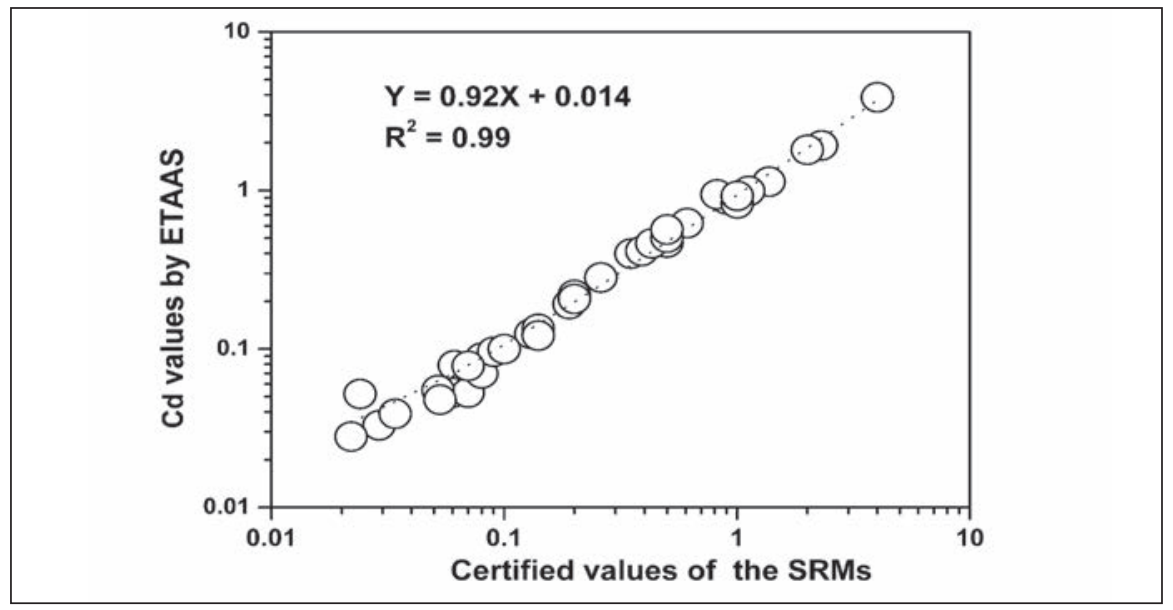

Fig. 3. Cd values determined by our ETAAS method vs the certified values for 39 Chinese geological SRMs.

TABLE III

Updated Cd Values for Some SRMs Determined by this Method ( $\mu \mathrm{g} \mathrm{g}^{-1}$ )

\begin{tabular}{lcc} 
Chinese Geological SRMs & This Work $(\mathrm{N}=10)$ & Certified Values \\
\hline GBW07101 Ultrabasic Rock & $0.052 \pm 0.004$ & $(0.024)^{\mathrm{a}}$ \\
GBW03103 Clay & $0.116 \pm 0.010$ & $-{ }^{\mathrm{b}}$ \\
\hline
\end{tabular}

${ }^{a}$ Reference value.

${ }^{\mathrm{b}}$ No reported value. tent results were obtained, indicating that our determined values are reasonable.

The method we report herein was also used to determine $\mathrm{Cd} \mathrm{lev-}$ els in 40 Chinese geological SRMs, including 5 soil, 24 rock, and 11 sediment standards. The results we obtained and their certified values are shown in Figure 3, except for the GBW03103 Clay, which has no available certified or literature values. The Cd levels of 38 of the geological SRMs are in good agreement with the certified or reference values. However, the Cd found in GBW07101 Ultrabasic Rock was $0.052 \pm 0.004 \mu \mathrm{g} \mathrm{g}^{-1}$, which is twofold higher than the reference value of $0.024 \mu \mathrm{g} \mathrm{g}^{-1}$. We digested and reanalyzed this SRM 10 times over a three-month period, and the results ranged from 0.048 to $0.056 \mu \mathrm{g} \mathrm{g}^{-1}$ (Table III). The SRM GBW03103 Clay (no reported Cd value available) was analyzed similarly and had a Cd level of $0.116 \pm 0.010 \mu \mathrm{g} \mathrm{g}^{-1}$ (Table III).

\section{CONCLUSION}

A valid method using closed vessel acid digestion ETAAS to accurately determine trace $\mathrm{Cd}$ in various geological samples has been developed. The Cd levels determined for 47 international geological SRMs are in good agreement with their certified or literature values. The method reported herein has also been used to determine the Cd levels of four SRMs (DNC-1a Dolerite, GSP-2 Granodiorite, COQ-1 Carbonates, and GBW03103 Clay) for which there are no previously reported Cd values. This method has great potential for the accurate determination of ultra-low levels of $\mathrm{Cd}\left(<0.2 \mu \mathrm{g} \mathrm{g}^{-1}\right)$ in various geological samples.

\section{ACKNOWLEDGMENTS}

This work was supported by the National Nature Science Foundation of P.R. China (No. 21175120 and 


\section{Atomic $_{\text {Spectroscopy }}^{\text {to }}$ \\ 1 Vol. 36(3), May/June 2015}

21207120), the National Key Scientic Instrument and Equipment Development Projects of China (No. 2011YQ06010008), and the Fundamental Research Funds for the China University of Geosciences (Wuhan) (No. CUGL140411).

Received February 22, 2015.

\section{REFERENCES}

1. A.D. Schmitt, S.J.G. Galer, and W. Abouchami, Earth. Planet. Sci. Lett. 277(1-2), 262 (2009).

2. H. Heinrichs, B. Schulz-Dobrick, and K.H. Wedepohl, Geochim. Cosmochim. Acta 44(10), 1519 (1980).

3. E.A. Boyle, F. Sclater, and J.M Edmond, Nature 263, 42 (1976).

4. R. Rey-Rubio, J. Moreda-Pineiro, E. Alonso-Rodriguez, P. Lopez-Mahia, S. Muniategui-Lorenzo, and D. Prada-Rodriguez, At. Spectrosc 33(6), 179 (2012)

5. R. A. Lagad, D.Alamelu, A.K. Chaudhary, and S.K. Aggarwal, At. Spectrosc. 33(4), 109 (2012)

6. V. Balaram, M. Satyanarananan, D.V. Aveev, N. Berdnikov, P. Roy, S.S Sawant, K.S.V. Subramanyam, K.V Anjaiah, C.T. Kamala, R. Mathur, and B. Dasaram, At. Spectrosc. 33(2), 41 (2012).

7. W. Guo, S.H. Hu, J.Y. Zhang, Z.C. Hu, H.F. Zhang, and Y.X. Wang, Talanta 91, 60 (2012).

8. W. Guo, S.H. Hu, J. Zhao, S.S. Jin, W.J. Liu, and H.F. Zhang, Microchem. J. 97, 154 (2011).

9. T.W. Way and R.H. Wiedmeyer, At. Spectrosc. 19(5), 150 (1998)

10. T.C. Duan, X.J. Song, P.G. Guo, H.F. Li, L.H. Pan, H.T. Chen, and J.W. $\mathrm{Xu}, \mathrm{J}$. Anal. At. Spectrom. 22, 403 (2007).

11. T.J. Hwang and S.J. Jiang, J. Anal. At. Spectrom. 12, 579 (1997).

12. Y. Suzuki, Y. Endo, M. Ogawa, M. Matsuda, Y. Nakajima, N. Onda, M Iwasaki, and S. Tsugane, Anal. Sci. 24, 1049 (2008)
13. H.W. Liu, S.J. Jiang, and S.H. Liu, Spectrochim. Acta B 54, 1367 (1999).

14. Z.C. Wang, H. Becker, and F. Wombacher, Geostand. Geoanal. Res. DOI: $10.1111 / \mathrm{j} .1751$ 908X.2014.00312.x (2014)

15. W. Guo, S.H. Hu, Y.F. Xiao, H.F. Zhang, and X.J. Xie, Chemosphere 81(11), 1463 (2010).

16. L.Y. Zhang, and Z.F. Fan, At. Spectrosc. 34(1), 26 (2013).

17. Y.J. Li, G.H. Hou, B. Zhou, and Y.L. Wei, At. Spectrosc. 33(4), 130 (2012).

18. F.M. Fortunato, J.A.G. Neto, and G.P.G. Freschi, At. Spectrosc. 33(4), 138 (2012).

19. W. Guo, P. Zhang, L.L. Jin, and S.H. Hu, J. Anal. At. Spectrom. 29(10), 1949 (2014)

20. P.J. Purohit, N. Goyal, and S.V. Godbole, At. Spectrosc. 33(3), 92 (2012).

21. R.A. Sanchez-Moreno, M.J. Gismera, M.T. Sevilla, and J.R. Procopio, Phytochem. Anal. 21, 340 (2010).

22. A. Makishima, and E. Nakamura, Geostand. Geoanal. Res. 35(1), 57 (2011).

23. C. Bouman, T. Elliott, and P.Z Vroon, Chem. Geology. 212(1), 59 (2004).

24. S.K. Marx and B.S. Kamber, Appl. Geochem. 25(8), 1221 (2010).

25. Z.C. Hu and S. Gao, Chem. Geology 253(3), 205 (2008).

26. R.D. Loss, K.J.R. Rosman, and J.R. De Laeter, Geochem. Cosmochim. Acta 48(8), 1677 (1984). 